\title{
Lethality of Crude Oil Contamination on Properties of Soil and Growth Parameters of Maize (Zea mays L.).
}

\author{
Agim LC*, Amos HI, Osisi AF, Okoli HN and Egboka NT \\ Department of Soil Science, Federal University of Technology, Nigeria
}

Submission: June 10, 2021; Published: July 06, 2021

*Corresponding author: Agim LC, Department of Soil Science, Federal University of Technology, P.M.B 1526, Owerri, Nigeria. P.M.B 1526, Owerri, Nigeria

\begin{abstract}
The knowledge of the impact of crude oil contamination is important for effective and sustainable environmental conservation. $20 \mathrm{~kg}$ of plough layer soil was bagged and arranged in a complete randomized design. Crude oil at seven treatment rates of 0,10, 20,30,40,50, and 60ml replicated thrice were poured, mixed, and allowed for two weeks before corn was planted. The experiment lasted for 3 months. Soil samples collected before and after the study were analyzed using standard laboratory methods. Maize growth parameters were collected at 4, 8, and 12 weeks after planting (WAP) respectively. Generated soil and plant data were subjected to analyses of variance (ANOVA). Results showed significant $(\mathrm{P}<0.05)$ increase in bulk density, moisture content, $\mathrm{pH}$, organic carbon with increasing rates of pollution. At 12 WAP like other intervals, leaf area index, plant height, dry matter yield in crude oil polluted soil were lower than the control.
\end{abstract}

Keywords: Crude oil spillage; Environmental pollution; Soil sustainability; Maize growth; Food security

\section{Introduction}

Crude is unrefined oil found underground [1] that is majorly composed of a complex mixture of hydrocarbons, metals, and organic compounds in their variants. These products are of particular concern to studies of pollution due to their none, little, and slow biodegradability potential and serious health implications associated with its release into the environment. Man's activities connected with crude oil refining have their pecuniary impacts on the locality. Crude mining through exploration and exploitation often leads to oil spillage [2], affecting the ecology [3] hence a chief source of environmental stress [4,5] notably in countries that produce oil such as Nigeria [6].

Notable adverse effects of crude oil on soil include hampering soil physical processes by the sealing and clogging of pore spaces which limit aeration and infiltration rate, root restriction, and overland flow of water through an increase in bulk density. Other affected physical and chemical soil properties are saturated hydraulic conductivity and water permeability [7], soil acidity, total nitrogen, heavy metal concentration, exchangeable cations, and organic matter content [8]. In crops, significant harm on the physiological functioning [9] brownish/yellowish vegetation [10], reduced crop biomass [11], stunted growth, leaf chlorosis, and plant dehydration [12] have been reported. Oil spillage according to $[13,14]$ affect the germinability of plants by forming a film that prevents oxygen from entering the seed [15] and masking the conditions that make plant important nutrients available $[16,17]$. Underground water quality [3] and aquatic lives were not in exception [9].

Corn or maize, belonging to the family of grasses known as Poaceae took its origin from Mexico [18]. It is morphologically stout, erect with a solid stem, and has the leaves arranged on the opposite side of the stem in alternate positions [18]. According to [19] the wide environmental adaptability, human and animal food/feed, and income generation [20,21]) made Zea mays L. the most important cereal next to rice and wheat grown in the world. The production of maize is masked with many constraints especially nutrient deficiency. Despite the global maize production projected to increase by $181 \mathrm{Mt}$ in 2028 [22] to feed the increasing human population expected to hit 8.5 billion by 2030 [23] the need for more maize production will continue to grow especially in upcoming countries [24]. This accounts for why [20], predicted more than 60Mt of corn to meet global demand. The competing demand for maize by animals will continue to put pressure on maize production [25].

Soil, the most valuable but vulnerable ecosystem component sustainable use is at risk today. Studies on the lethality of crude oil spillage on the soil are majorly based on onsite field studies, 
but the high-security challenges on oil spill sites and nearby farms made holistic researches very difficult. Knowledge is a continuum and efforts made to update existing information especially on agriculturally endangered zones are highly needed. Due to the above reasons, this work is mainly aimed at determining the effects of crude oil contamination on properties of soil and growth parameters of maize (Zea mays L.). Specifically, the study determined:

i. crude oil contamination on soil physical and chemical properties, growth parameters of maize in pot and on field experiments.

ii. Comparisons were made between selected results of both experiments with those at the initiation of the study.

\section{Materials and Methods}

\section{Study area}

The research was done at the Center for Agricultural Research and Extension (CARE) garden of the Federal University of Technology Owerri, Nigeria which is located on latitude $5^{0} 21^{\prime} \mathrm{N}$ and $5^{\circ} 28^{\prime} \mathrm{N}$ and Longitude $7^{0} 11^{\prime} \mathrm{E}$ and $7^{\circ} 45^{\prime} \mathrm{E}$. The soil, classified as Typic Isohyperthermic Peleudult [26] belongs to the Beni formation geological group $[27,28]$. They are characterized with high weatherability and leaching, low organic carbon content, low in exchangeable cation, and high acidity [29]. The average annual rainfall, temperature, and relative humidity are $2500-3000 \mathrm{~mm}$, $27-30$, and $79 \%$ [30]. The original tropical rain forest vegetation is now replaced by secondary forest as a result of anthropogenic activities and an increase in the human population. The major occupation of the inhabitants is farming where maize, cassava, cocoyam, and yam are the major crops produced.

\section{Soil collection and contamination}

Surface soil samples $(0-15 \mathrm{~cm}$ depth) were collected with the standard procedure of soil sampling. $20 \mathrm{~kg}$ of the collected samples were bagged and arranged on the farm in a complete randomized design. Crude oil (Bonny light) sourced from Agip Nigeria at seven (7) treatment rates of $0,10,20,30,40,50$, and $60 \mathrm{ml}$ were poured in each plot respectively. Each treatment was replicated thrice making a total of 21 plots or bags used. The bags were perforated to allow drainage of excess water from the bag. Two meters away from where the bags were placed field experiment was established on an area of $99.225 \mathrm{~m}^{2}(15.75 \mathrm{X} 6.30 \mathrm{~m})$ representing $0.00925 \mathrm{ha}$. The essence for establishing both experiments in the same place was to make sure that they receive the same climatic variables such as rainfall, temperature etc).

Firstly, the area was cleared and later minimally manipulated or tilled. Also 21 plots now in Randomized Complete Block Design were established. Crude oil at the same rates and replicates above was poured directly around the tilled area. Both experiments were simultaneously monitored for two weeks before planting took place. Maize accessions used for the study was sourced from
Agricultural Development Program (ADP) office Owerri. Three (3) seeds were planted per hole at an intra-row spacing of $0.25 \mathrm{~m}$ and inter-row spacing of $0.75 \mathrm{~m}$ and later thinned down to one plant per hole at three weeks after planting giving a theoretical plant population of 33,333 plants per hectare. Planting was done on the 13th of May, 2019 during the 2019 cropping season. Agronomic practices were also carried out in both studies.

The reason for establishing both experiments above were to determine if pot experiments results could be substituted to field results especially in high security challenge areas. Again, the comparison of pot experiments results to those of field conditions are limited.

\section{Data collection procedure}

Growth factors of maize were collected at 4, 8, and 12 weeks after planting (WAP). The height of the plant was taken from the base to the terminal bud with a measuring tape. Leaf area index (LAI) was measured by multiplying the length (L) and width (W) of the longest leaf in each plot with a 0.75 correction factor for maize (L X W X 0.75) as was prescribed by [31] Dry matter yield was achieved by harvesting the leave and stem of the maize plant at maturity and air drying them for one week after which they were weighed. Plant structural efficiency was calculated by dividing dry matter yield with the leaf area index. Soil samples to be analyzed in the laboratory were taken at the end of the experiment.

\section{Laboratory analyses}

Soil analyses at both the initiation of the study (before the study commenced) and after pollution were determined following the standard procedure of the documented researchers as follows: Particle size fractions [32], bulk density [33], total porosity [34], soil moisture content [35], pH in water [36], organic carbon [37], total nitrogen [38], available phosphorus [39], exchangeable acidity, sodium and potassium [40], calcium and magnesium [41], effective cation exchange capacity (ECEC) [34] respectively.

\section{Data analyses}

Generated plant and soil data were subjected to analysis of variance (ANOVA) to detect significant differences between treatment means and Fisher's least significant difference (F-LSD was used for mean separation at $5 \%$ level of probability.

\section{Results}

\section{Physical properties of the studied soil following crude oil pollution}

Results of the physical properties of studied soil following crude oil pollution are presented in Table 1 . Crude oil pollution did not significantly $(\mathrm{P}<0.05)$ affect particle sizes in the pot and field experiments, however individual percentage fractions changed, a result similar to [42]. In both studies, sand and silt fractions increased with an increase in rates of application. Sand, silt and clay fractions varied from 738.10, 120.42, 141.48g $\mathrm{kg}^{-1}$ 
at control (zero pollution rate) to $764.02,135.06 ; 100.92 \mathrm{gkg}^{-1}$ at $60 \mathrm{ml}$ pollution rate in the pot experiment and $741.34,122.34$, $136.32 \mathrm{gkg}^{-1}$ at control (zero pollution rate) to 760.16 ; 139.22 ; $100.62 \mathrm{~g} \mathrm{~kg}^{-1}$ at $60 \mathrm{ml}$ pollution rate in field experiment. Bulk density, which was significantly $(\mathrm{p}<0.05)$ affected by crude oil pollution in both studies progressively increased with an increase in rates of pollution. $[43,14]$ found higher bulk density values in soil polluted with crude oil. Bulk density ranges from $1.42 \mathrm{gcm}$ ${ }^{3}$ at control ( 0 pollution rate) $-1.67 \mathrm{gcm}^{-3}$ at $60 \mathrm{ml}$ pollution rate in the potted experiment and from $1.34-1.69 \mathrm{gcm}^{-3}$ at the same pollution rates in the field studies (Table 1). It is note-taking that oil pollution raised bulk density above the $1.2 \mathrm{gcm}^{-3} \mathrm{critical}$ level for tropical soils documented by [44] to $1.69 \mathrm{gcm}^{-3}$ which is for soils with high compaction characteristics, low structural development, and high cohesion [45]. A comparison of bulk density values (Figure 1) after crude oil pollution to those of the initial values (before the commencement of the work) in Table 2 , still emphasized the impact crude oil has on the soil. Moisture content differed significantly $(\mathrm{P}<0.05)$ with the rates of crude oil pollution. The highest $745.93 \mathrm{gkg}^{-1}$ and lowest $450.35 \mathrm{gkg}^{-1}$ values (pot experiment), 778.33 and $452.32 \mathrm{gkg}^{-1}$ (field experiment) occurred at 60 and $0 \mathrm{ml}$ (control) pollution rates respectively. $[14,46,47]$ found higher moisture content in soils spilled with oil than unpolluted soils. The impact of crude oil pollution on moisture content was higher in the pot experiment compared to the initial values (Table 2) and those on the field (Figure 1).

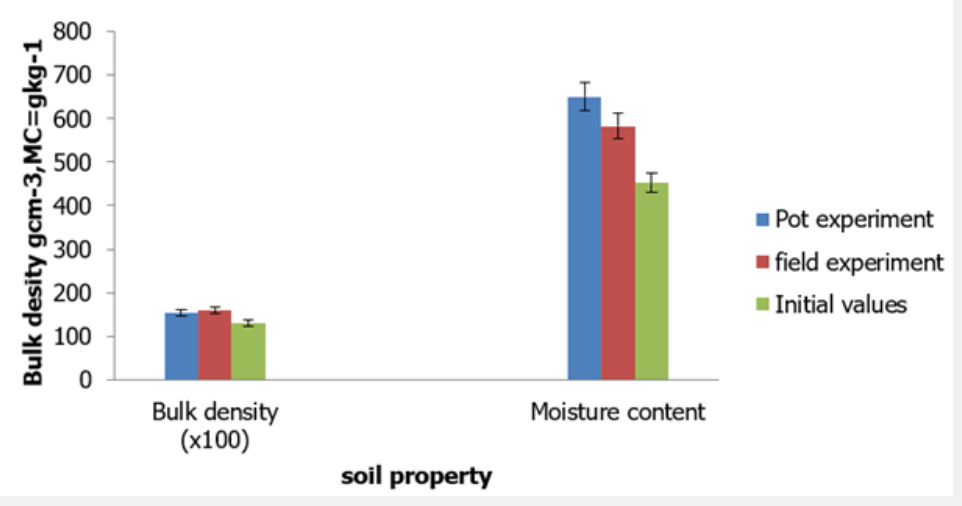

Figure 1: Comparison of soil moisture content and bulk density in contaminated soils with initial values.

Table 1: Physical Properties of studied soil in both pot experiments and directly on the field.

\begin{tabular}{|c|c|c|c|c|c|c|c|}
\hline Pollution rate $\mathrm{ml} / 20 \mathrm{~kg}$ soil & Sand gkg ${ }^{-1}$ & Silt gkg-1 & Clay gkg ${ }^{-1}$ & Textural Class & $\mathrm{BD} \mathrm{gcm}^{-3}$ & Тр \% & Mcgkg-1 $^{-1}$ \\
\hline \multicolumn{8}{|c|}{ Pot Experiment } \\
\hline 0 & 738.1 & 120.42 & 141.48 & Sandy loam & 1.42 & 51.77 & 450.35 \\
\hline 10 & 740.11 & 121.08 & 138.81 & Sandy loam & 1.57 & 40.84 & 562.32 \\
\hline 20 & 746.33 & 132.89 & 129.78 & Sandy loam & 1.58 & 40.46 & 673.21 \\
\hline 30 & 751.16 & 128 & 120.84 & Sandy loam & 1.61 & 39.34 & 690.32 \\
\hline 40 & 757.17 & 129.11 & 113.72 & Sandy loam & 1.64 & 38.21 & 705.45 \\
\hline 50 & 760.72 & 132.44 & 106.84 & Sandy loam & 1.65 & 37.83 & 720.32 \\
\hline 60 & 764.02 & 135.06 & 100.92 & Sandy loam & 1.67 & 37.07 & 745.93 \\
\hline LSD $(P<0.05)$ & NS & NS & NS & & $0.02^{*}$ & $2.12^{*}$ & $10.21 *$ \\
\hline \multicolumn{8}{|c|}{ Field Experiment } \\
\hline 0 & 741.34 & 122.34 & 136.32 & Sandy loam & 1.41 & 53.27 & 452.32 \\
\hline 10 & 754.68 & 123.11 & 132.21 & Sandy loam & 1.53 & 42.35 & 460.21 \\
\hline 20 & 746.61 & 128.21 & 125.18 & Sandy loam & 1.57 & 40.48 & 465.22 \\
\hline 30 & 747.84 & 131.16 & 121 & Sandy loam & 1.64 & 38.21 & 576.45 \\
\hline 40 & 756.11 & 136.72 & 107.17 & Sandy loam & 1.68 & 36.69 & 677.18 \\
\hline 50 & 758.65 & 138.19 & 103.16 & Sandy loam & 1.69 & 36.32 & 670.45 \\
\hline 60 & 760.16 & 139.22 & 100.62 & Sandy loam & 1.69 & 36.32 & 778.33 \\
\hline LSD $(P<0.05) F 21: M 33$ & NS & NS & NS & & $0.33^{*}$ & $1.12^{*}$ & $9.23^{*}$ \\
\hline
\end{tabular}

$\mathrm{Ns}=$ not significant, $\mathrm{P}=$ probability level, $\mathrm{BD}=$ bulk density, $\mathrm{TP}=$ total porosity, $\mathrm{MC}=$ moisture content, ${ }^{*}=$ Significant. 
Table 2: Initial physical and chemical properties of the studied soil.

\begin{tabular}{|c|c|c|c|c|c|c|c|c|c|c|}
\hline \multicolumn{11}{|c|}{ Physical Properties } \\
\hline $\begin{array}{l}\text { Sand } \\
\mathrm{gkg}^{-1}\end{array}$ & Silt gkg $^{-1}$ & $\begin{array}{l}\text { Clay } \\
\text { gkg }^{-1}\end{array}$ & Textural class & $\begin{array}{l}\text { Bulk density } \\
\mathrm{gcm}^{-3}\end{array}$ & $\begin{array}{l}\text { Moisture } \\
\text { content } \\
\mathrm{gkg}^{-1}\end{array}$ & & & & & \\
\hline 763.32 & 100.2 & 136.48 & Sandy loam & 1.3 & 452.39 & & & & & \\
\hline \multicolumn{11}{|c|}{ Chemical Properties } \\
\hline $\begin{array}{l}\mathrm{pH} \text { (wa- } \\
\text { ter) }\end{array}$ & $\begin{array}{l}\mathrm{TOC} \\
\mathrm{gkg}^{-1}\end{array}$ & 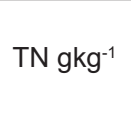 & $\begin{array}{c}\text { Available } \\
\text { Phosphorus } \\
\text { mgkg-1 }^{-1}\end{array}$ & Ca cmolkg-1 & $\begin{array}{c}\mathrm{Mg} \\
\mathrm{cmolkg}^{-1}\end{array}$ & $\begin{array}{c}\mathrm{Na} \\
\text { cmolkg-1 }^{-1}\end{array}$ & $\begin{array}{c}\mathrm{K} \\
\text { cmolkg-1 }^{-1}\end{array}$ & $\begin{array}{c}\mathrm{H}+ \\
\text { cmolkg-1 }^{-1}\end{array}$ & $\begin{array}{c}\mathrm{Al}^{3+} \\
\mathrm{cmolkg}^{-1}\end{array}$ & $\begin{array}{l}\text { ECEC } \\
\text { cmolkg-1 }^{-1}\end{array}$ \\
\hline 5.32 & 15.26 & 6.71 & 11.29 & 2.12 & 1.12 & 0.1 & 0.2 & 0.31 & 2.45 & 6.3 \\
\hline
\end{tabular}

$\mathrm{Ca}=$ Calcium, $\mathrm{Mg}=$ magnesium, $\mathrm{Na}=$ Sodium, $\mathrm{K}=$ Potassium, $\mathrm{H}=$ Hydrogen, $\mathrm{Al}=$ Aluminium .

ECEC=Effective cation exchange capacity, TOC=Total organic carbon.

\section{Chemical properties of the studied Soil following crude oil contamination}

Table 3: Chemical properties of studied soils at the green house and directly on the field.

\begin{tabular}{|c|c|c|c|c|c|c|c|c|c|c|c|c|c|}
\hline $\begin{array}{c}\text { Pollution } \\
\text { Rate MI }\end{array}$ & $\begin{array}{c}\mathrm{pH} \\
\mathrm{H}_{2} \mathrm{O}\end{array}$ & $\begin{array}{l}\text { TOC } \\
\text { gkg }^{-1}\end{array}$ & $\begin{array}{l}\text { TN } \\
\%\end{array}$ & $\begin{array}{c}\text { AP } \\
\text { mgkg }^{-1}\end{array}$ & $\begin{array}{c}\text { Ca } \\
\text { cmolkg }^{-1}\end{array}$ & $\underset{\text { cmolkg }^{-1}}{\mathrm{Mg}}$ & $\begin{array}{c}\mathrm{Na} \\
\text { cmolkg }^{-1}\end{array}$ & $\underset{\text { cmolkg }^{-1}}{\mathbf{K}}$ & $\underset{\text { cmolkg }^{-1}}{\mathrm{H}+}$ & $\underset{\text { cmolkg }^{-1}}{\mathrm{Al3}+}$ & $\begin{array}{c}\text { TEA } \\
\text { cmolkg-1 }^{-1}\end{array}$ & $\begin{array}{c}\text { TEB } \\
\text { cmolkg }^{-1}\end{array}$ & $\begin{array}{c}\text { ECEC } \\
\text { cmolkg }^{-1}\end{array}$ \\
\hline \multicolumn{14}{|c|}{ Pot Experiment } \\
\hline 10 & 5.38 & 14.4 & 6.5 & 11.3 & 2.72 & 1.39 & 0.13 & 0.28 & 1.72 & 0.04 & 1.76 & 4.52 & 6.28 \\
\hline 20 & 5.4 & 23.41 & 6.3 & 10.21 & 3.5 & 1.55 & 0.13 & 0.34 & 1.42 & 0.32 & 1.74 & 5.52 & 7.26 \\
\hline 30 & 5.65 & 24.3 & 6.9 & 9.86 & 3.61 & 1.95 & 0.14 & 0.28 & 1.68 & 0.59 & 2.27 & 5.98 & 9.25 \\
\hline 40 & 5.76 & 23.48 & 7.3 & 9.21 & 2.64 & 2.99 & 0.14 & 0.29 & 1.06 & 2.25 & 3.31 & 6.06 & 9.37 \\
\hline 50 & 5.74 & 16.85 & 6.99 & 8 & 3.87 & 2.91 & 0.14 & 0.29 & 1.47 & 1.8 & 3.27 & 7.21 & 12.48 \\
\hline 60 & 6.26 & 44.28 & 7.5 & 9.46 & 3.87 & 2.97 & 0.16 & 0.31 & 1.9 & 2.32 & 2.11 & 7.31 & 11.52 \\
\hline $\begin{array}{l}\text { Con- } \\
\text { trol }(0)\end{array}$ & 5.37 & 11.69 & 5.6 & 13.33 & 2.13 & 1.32 & 0.12 & 0.25 & 0.34 & 2.33 & 2.67 & 6.69 & 6.69 \\
\hline $\begin{array}{c}\text { LSD } \\
(\mathrm{P}<0.05)\end{array}$ & $0.21^{*}$ & $0.24 *$ & NS & $3.45^{*}$ & 0.21 & 1 & NS & $0.05^{*}$ & $0.21^{*}$ & $0.14^{*}$ & $0.98^{*}$ & $1.02^{*}$ & $1.34^{*}$ \\
\hline \multicolumn{14}{|c|}{ Field Studies } \\
\hline 10 & 5.7 & 15.72 & 6 & 12.26 & 2.78 & 1.4 & 0.16 & 0.2 & 1.64 & 0.15 & 1.79 & 4.54 & 6.33 \\
\hline 20 & 5.78 & 15.83 & 6.32 & 11 & 2.56 & 1.54 & 0.16 & 0.31 & 1.43 & 0.31 & 1.74 & 4.57 & 6.31 \\
\hline 30 & 5.87 & 14.33 & 7.02 & 10.16 & 4.06 & 1.9 & 0.14 & 0.28 & 1.6 & 0.43 & 2.03 & 6.38 & 8.41 \\
\hline 40 & 5.96 & 18.22 & 6.53 & 9.24 & 2.9 & 2 & 0.16 & 0.3 & 1.08 & 1.98 & 3.06 & 5.36 & 8.42 \\
\hline 50 & 6.1 & 22.16 & 7.88 & 8.47 & 4.09 & 3 & 0.17 & 0.232 & 1.84 & 1.43 & 3.27 & 7.49 & 11.75 \\
\hline 60 & 6.35 & 22.89 & 7.9 & 6.48 & 3.67 & 2.76 & 0.18 & 0.22 & 1.87 & 1.39 & 3.26 & 6.83 & 11.09 \\
\hline $\begin{array}{l}\text { Con- } \\
\text { trol(0) }\end{array}$ & 5.36 & 11.69 & 6.6 & 13.3 & 2.13 & 1.32 & 0.12 & 0.21 & 0.34 & 2.33 & 2.67 & 6.69 & 6.69 \\
\hline $\begin{array}{c}\text { LSD }(\mathrm{P}< \\
0.05)\end{array}$ & $0.45^{*}$ & $0.54^{*}$ & NS & $2.44^{*}$ & $1.32^{*}$ & $1.29 *$ & NS & $0.06^{*}$ & $0.14^{*}$ & $0.15^{*}$ & $1.00^{*}$ & $1.06^{*}$ & $1.04^{*}$ \\
\hline
\end{tabular}

The results of the chemical properties of the studied soil are presented in Table 3. Soil $\mathrm{pH}\left(\mathrm{H}_{2} \mathrm{O}\right)$ differed significantly ( $\mathrm{P}$ $<0.05$ ) among the levels of pollution in both the field and pot experiments respectively. In a progressive manner, soil $\mathrm{pH}$ tended towards alkalinity from $10 \mathrm{ml}$ (5.38 and 5.70$)$ to $60 \mathrm{ml}(6.26$ and 6.35 ) in experiments conducted in the pot and directly on the field respectively. The results were higher than the respective control values of 5.36 and 5.37. Soil organic carbon ranged from $14.40 \mathrm{gkg}$
${ }^{1}$ at $10 \mathrm{ml}$ to $44.28 \mathrm{gkg}^{-1}$ at $60 \mathrm{ml}$ pollution rate in pot experiment and from $14.33 \mathrm{gkg}^{-1}$ at $30 \mathrm{ml}$ to $22.89 \mathrm{gkg}^{-1}$ at $60 \mathrm{ml}$ pollution in the field experiment. The result of the experiment is in agreement with [48]. Results showed that soil organic carbon increased with increasing rates of oil pollution except at $50 \mathrm{ml}$ pollution rate $\left(16.85 \mathrm{gkg}^{-1}\right)$ on the pot experiment and $30 \mathrm{ml}$ pollution $(14.33 \mathrm{gkg}$ $\left.{ }^{1}\right)$ on field experiment. [3,43] found progressive higher values of organic carbon following an increase in the rates of crude oil 
pollution in a soil. Total nitrogen of the studied soils though not significant at $5 \%$ probability level in both studies ranged from 5.60 to $7.50 \mathrm{gkg}^{-1}$ in pot experiment and from 6.0 to $7.90 \mathrm{gkg}^{-1}$ at $10 \mathrm{ml}$ and $60 \mathrm{ml}$ pollution rates in field studies. The high values of total nitrogen in polluted soils were similar but higher than those of [47] in the same area who obtained total nitrogen values ranging from $2.80 \mathrm{gkg}^{-1}$ in unpolluted soils to $3.40 \mathrm{gkg}^{-1}$ on soil polluted with spent engine oils. Available phosphorus markedly decreased with an increase in the rate of crude oil pollution in both studies. Critical limits of available phosphorus determined by [39] method in soil varies from high ( $\left.>15 \mathrm{mgkg}^{-1}\right)$, medium $\left(15-5 \mathrm{mgkg}^{-1}\right)$ and low $\left(<5 \mathrm{mgkg}^{-1}\right)$ [44]. Based on the above, the results in the present study were medium $9.21-13.33 \mathrm{mgkg}^{-1}$ at 40 and $0 \mathrm{ml}$ pollution rates in pot experiment and $6.48-13.30 \mathrm{mgkg}^{-1}$ at 60 and $0 \mathrm{ml}$ (control) pollution rates. Total exchangeable bases
(TEB) presented in Table 3 differed significantly $(\mathrm{P}<0.05)$ in both pot and direct field experiments. They ranged from $4.52-7.31$ at 10 and $60 \mathrm{ml}$ pollution rates in the potted experiment and 4.54 $7.49 \mathrm{cmolkg}^{-1}$ in 10 and $50 \mathrm{ml}$ pollution rates in field studies. There was a progressive increase with an increase in pollution rates from 10 to $60 \mathrm{ml}$ pollution rates in pot experiments. The results in the field were inconsistent with increase in oil pollution rates. Result increased up to $30 \mathrm{ml}$ pollution rate $\left(4.54-6.38 \mathrm{cmolkg}^{-1}\right)$ dropped at $40 \mathrm{ml}\left(5.36 \mathrm{cmolkg}^{-1}\right)$, increased at $50 \mathrm{ml}$ pollution rate $\left(7.49 \mathrm{cmolkg}^{-1}\right)$ and dropped again at $60 \mathrm{ml}$ pollution rate $\left(6.83 \mathrm{cmolkg}^{-1}\right)$. In a comparison of the results obtained in pot and field experiments to those of initial soil samples, soil organic carbon, total nitrogen and effective cation exchange capacity were higher in pot experiment than those of field and initial values (Figure 2).

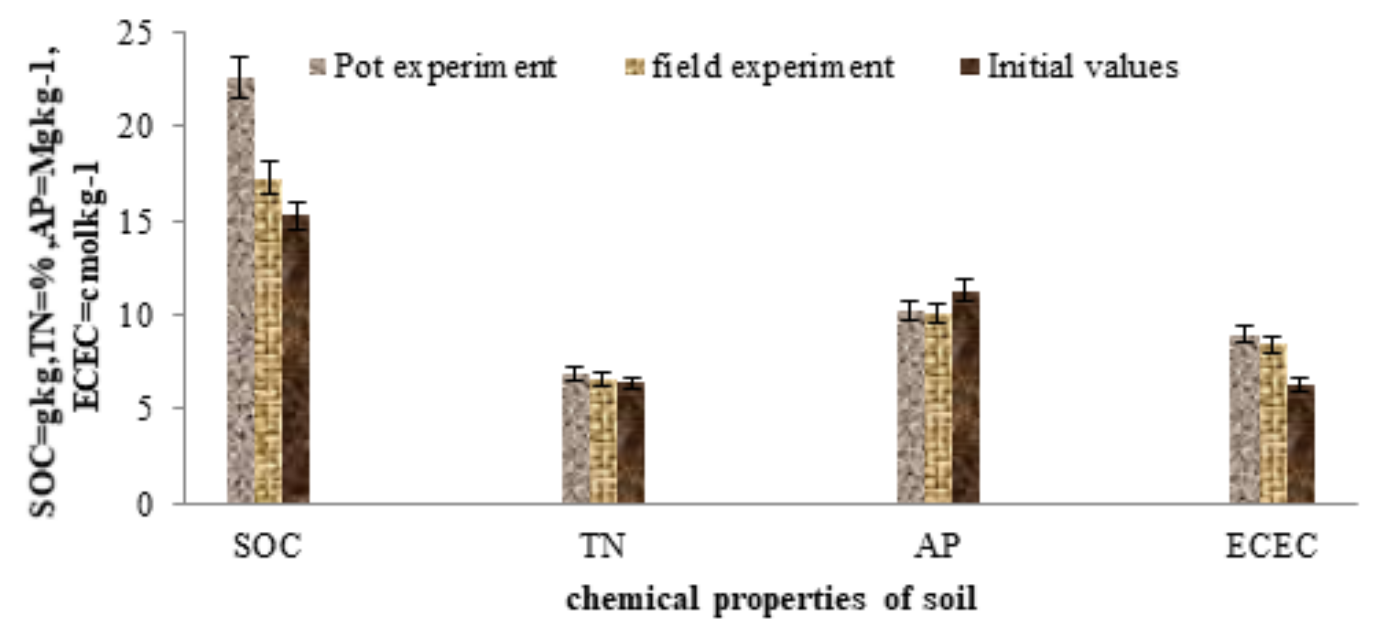

Figure 2: Comparison of selected chemical properties namely soil organic carbon (SOC), Total nitrogen (TN), Available phosphorus (AP) and effective cation exchange capacity (ECEC) of contaminated soils with the initial values obtained before the commencement of the study.

\section{Effect of crude oil pollution on maize parameters}

The results of the effects of the levels of crude oil pollution on plant height in both experiments are presented in Figure 3. The result showed a progressive reduction of plant height with increased levels of crude oil pollution. This continued as the weeks progressed from 4 to 12 after planting on field experiment. The same trend in pot experiment was observed except for results at 10 and $20 \mathrm{ml}$ pollution rates where there was an increase in plant height. Generally, plant height ranged from $20.60 \mathrm{~cm}$ at $60 \mathrm{ml}$ in $4 \mathrm{WAP}$ to $209.44 \mathrm{~cm} \mathrm{ml}$ at control on pot experiment and from $21.44 \mathrm{~cm}$ to $239.4 \mathrm{~cm}$ at the same levels of pollution on field studies respectively. [21], reported maize plant height values ranging from 33 to $199 \mathrm{~cm}$ at 4 and 8 WAP following crude oil pollution. These recorded values in height are far below $0.6 \mathrm{~m}$ $(600 \mathrm{~cm})$ height of matured maize as documented by [49]. The impact of crude oil on leaf area index, structural efficiency, and dry matter yield are presented in Figure $4 \& 5$ respectively. Leaf area index (LAI) significantly $(<0.05)$ differed among treatments means in both studies. The LAI was higher under control than in polluted soils which also decrease with an increase in the rate of pollution. Values ranging from $43.66-342.98 \mathrm{~cm}^{2}$ and $53.44-$ $376.44 \mathrm{~cm}^{2}$ were recorded at $60 \mathrm{ml}$ pollution rate at $4 \mathrm{WAP}$ and control at 12 WAP under pot and field experiment respectively (Figure 4). Dry matter yield took the same trend with the leaf area index only (Figure 5). The values were higher in the control $0 \mathrm{ml}$ than in polluted samples. The dry matter yield and leaf area index also affected the structural efficiency in Figure 5.

\section{Discussion}

The Increased values of sand and silt fraction with the increased rate of oil pollution in the field were similar to those of [50]. Similarly, $[14,7]$ found higher values of sand and lower clay fractions in unpolluted soil than in polluted soils. This could be caused by the concentration of the applied crude oil as [51] opined that crude oil above $3 \%$ concentration can mask the effectiveness of soil and crop. An increase in sand fraction may lead to an 
increase in pollution of underground water through the migration or infiltration of acrylamide [52,53] a component of crude oil into the soil [14]. Increased in silt fraction in comparison to those of zero pollution rate is attributed to soil compaction caused by the oil [50]. Despite the rates of crude oil pollution, the soil texture remained unchanged. This confirmed [34] who documented that soil texture cannot be changed easily. The textural classification of the studied soil was in line with [54] who opined that the texture of the surface horizon of soils of the humid tropics is dominated by sandy loam and loam. The high bulk density as a result of oil pollution is attributed to the gelatinous and lower emulsifying nature of crude oil [48]. [55] reported that oil in soil increases the weight thereby causing more stress to it. This development alters other properties like pore size distribution, aeration, and soil strength and as well may alter the free movement of microorganisms, water, nutrients in the soil and as a result affect the overall development of the crop through root restriction. Total porosity followed the same trend with bulk density. This report agrees with the observation of [56], who reported that an increase in bulk density is associated with decreased pore volume. The reduced pore space may create an anaerobic condition for soil organisms which can lead to their death. This may be the reason why $[48,53]$ attributed the change in the microbial population, enzyme structure and system, and death of organisms to oil pollution. This higher bulk density in field experiment compared to those of pot and of the initial values could be traced to land use, the surface area of the soil which may have affected the dissemination of oil and tillage effects compared to those in the pot. Higher moisture content following increased rates of crude oil application is attributed to low infiltration within the soil as a result of the high bulk density created by the pollution. The amount of organic carbon and its binding effects on soil aggregates increases the water retention of soil. The importance of moisture in soil cannot be overemphasized especially in nutrient release to plant, spark in activities of microorganism, and crop growth. High water content could be attributed to less evaporation of water to the atmosphere due to the coating and clogging of soil pores as a result of its hydrophobic nature. The higher moisture content in pot experiment could be attribution to low moisture loss to the atmosphere as a result of bagging.

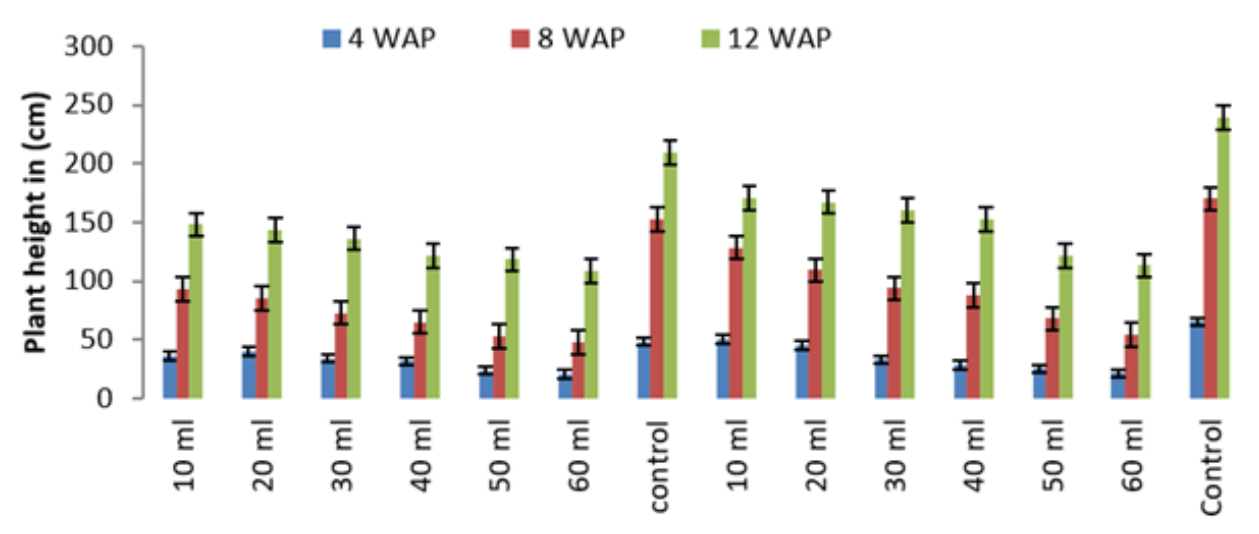

Pot experiment

Field experiment

Figure 3: Effect of crude oil pollution on plant height the pot and field experiments

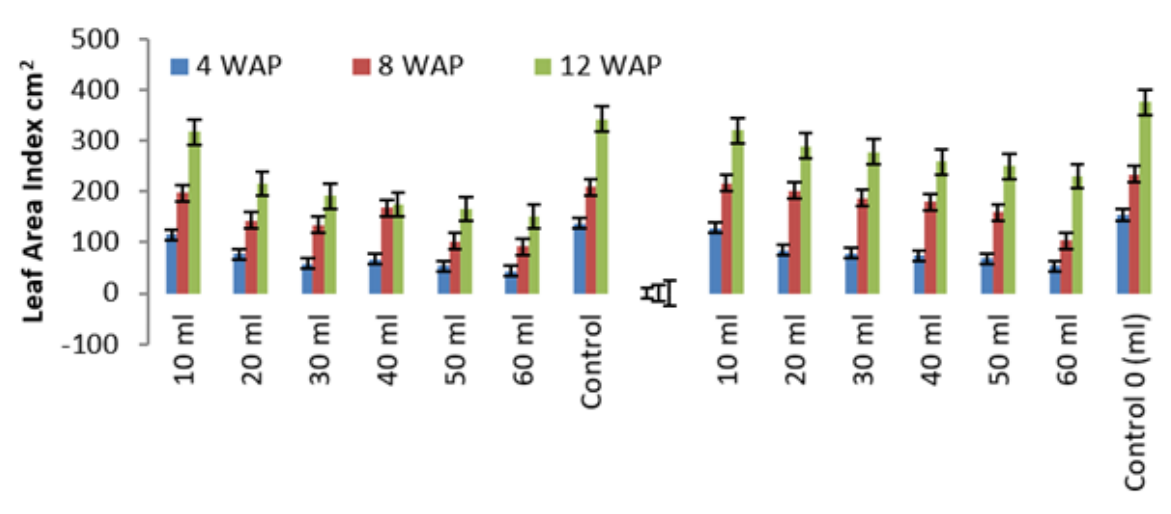

Pot experiment

field experiment

Figure 4: Effect of crude oil pollution on leaf area index of the pot and field experiments. 


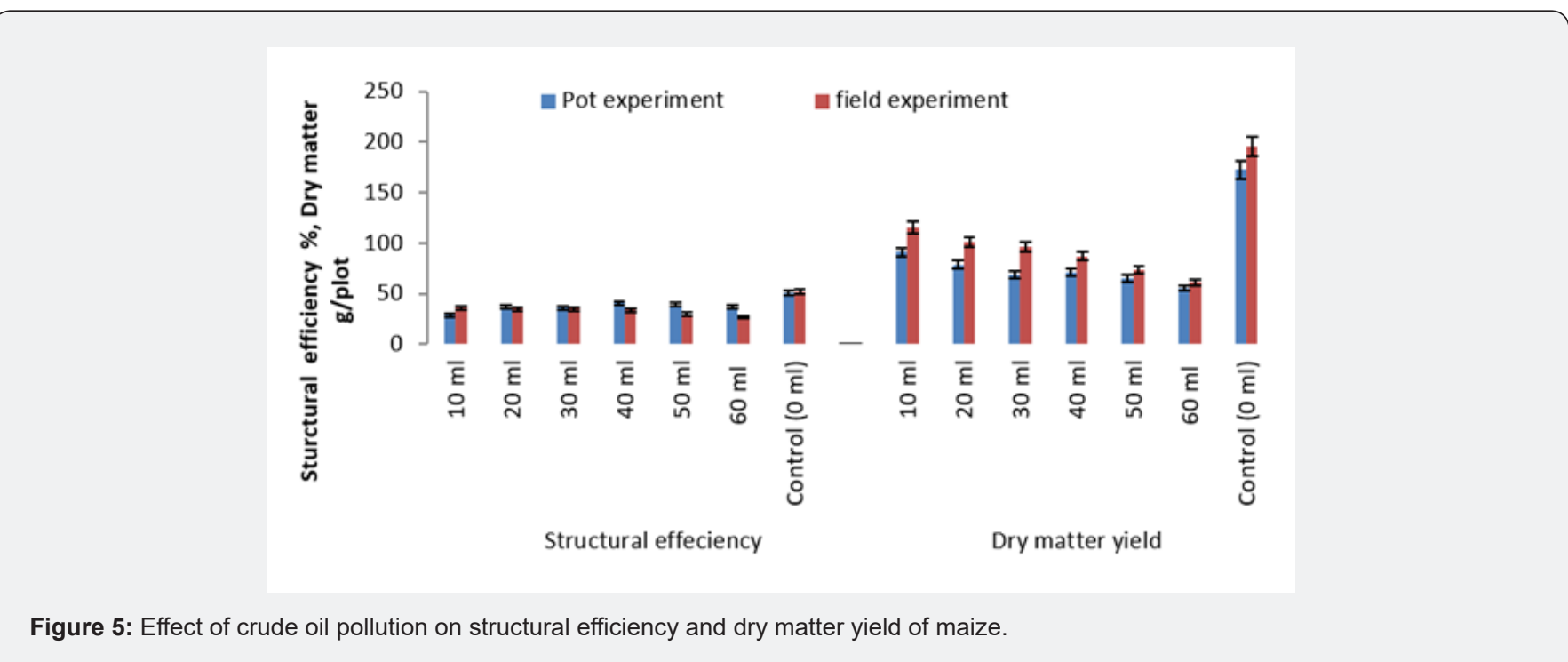

Our findings on soil $\mathrm{pH}$ were in disagreement with [14] who found lower values of $\mathrm{pH}$ with oil contaminated soil and the postulations of $[57,58]$ that crude oil pollution could lead to lower values of soil $\mathrm{pH}$. On the other hand our results strongly support [50] who found increase values of soil $\mathrm{pH}$ from 5.64 in control to 5.87 at $1000 \mathrm{ml} / 20 \mathrm{~kg}$ soil in soils of Cross River State Nigeria, [42] in working is soils of Romani, [46] on soils of China and [97] in China. [59] opined that soil $\mathrm{pH}$ values increases slightly with increasing values of oil treatment. These results were still acidic despite the increasing levels of pollution confirming the acidic nature of Isohyperthermic Typic Paleudult a factor attributed to parent material, high rainfall status of the area that leaches out soil basic cations [44] while leaving hydrogen and aluminium otherwise known as total exchange acidity [60] on soil surfaces. However, by raising the already acidic nature of the soil towards basicity, the oil must have modified the soil by activating basic cations notably calcium and sodium ions $[61,8]$ which push upward soil $\mathrm{pH}$ by increasing the ionic stability. Similarly, the carbon and nitrogen content of crude oil can change the components and structure of soil organic matter to affecting the soil $\mathrm{pH}$, electrical conductivity and $\mathrm{C} / \mathrm{N}$ ratio of the soil [62]. The hydrophobic nature of crude oil might have a way of creating potential drought $[63,64]$ on crude oil polluted soil surfaces. This makes the soil saline to an extent, a condition caused by high $\mathrm{pH}$ values in oil-polluted soils. [44] rated $\mathrm{pH}$ from 5.2 to 6.2 as moderate, while those from $6.2-6.9$ are rated weakly acidic. It is interesting to know that the $\mathrm{pH}$ ranges were still in the range for optimum performance of crops and microorganisms in soil all things being equal. The increased values of organic carbon are achieved through an oxidative coupling process as a result of long decayed components of plants and animal debris [65] of crude. The slow decomposition rate as a result of the adverse effects of crude oil on soil microbes could be another possible cause. According to [41] ratings of soil organic matter in tropical soils, all results both in polluted and unpolluted soils fall within the very low $\left(<2 \%\right.$ or $\left.20 \mathrm{gkg}^{-1}\right)$ and low $\left(2-4 \%\right.$ or $\left.20-40 \mathrm{gkg}^{-1}\right)$ category. This is typical of humid tropical soils which have been reported to be low in organic carbon. Organic matter calculated from of organic carbon $[34,66]$ plays an important role in improving soil physical, chemical, and biological properties. It has been reported that organic matter as a dynamic soil property [67] has influences on the soil pH, water holding capacity [34], colour, cation exchange capacity, base saturation and buffering capacity [68] and effective cation exchange capacity [69]. The colloidal property [70] of soil organic matter justifies its binding effects on soil aggregates stability, and infiltration of soils. However, these influences may be masked in soils due to the mutagenic property of crude oil. Higher values of soil organic are attributed to crude oil pollution and land use by [71]. Furthermore, the increased values of total nitrogen are attributed to the impact of crude in promoting organic carbon content of the soil. $[67,66,72]$ found a significant positive relationship of organic carbon with total nitrogen in soils. These results affirm the results of $[50,73,74]$ but disagree with $[75,76,77]$ who documented a decrease in total nitrogen with an increase in crude oil-polluted soil. The differences in total nitrogen following crude oil pollution compared values obtained by [47] could be attributed to the viscosity, density, and quality of the crude oil used to that of spent or condemned motor oil. [78] categorized total nitrogen content that is less than $2.5 \mathrm{gkg}^{-1}$ $(0.25 \%)$ which is typical of humid tropical soils [44], as being low. These results were a little higher than the critical level of total nitrogen for optimum crop production in soils of humid tropics documented by [79]. Adequate nitrogen levels in the soil help to increase the vegetative growth of the plant.

Available phosphorus together with nitrogen and potassium are the three most important macro elements that are highly needed in the soil for optimum crop production [80]. These important soil properties especially phosphorus is always having fixation problems due to the high acidity of humid tropical soils [81] and its availability therefore must be supported or aided with 
mineral fertilizer [44]. Phosphorus availability in soil indicates the proper photosynthetic ability of crops, proper root growth, firm stem stalk, early maturity, and flower coloration whereas its inadequacy implies impaired root growth, colouring of lower leaves of plants, etc [81]. Reduction in available phosphorus which affirmed the works of $[47,50,74,76]$ cut short the possible expectation of an increase in phosphorus availability due to the increase in soil $\mathrm{pH}$, soil organic carbon and nitrogen content following increased rates of oil pollution. The complex process of phosphorus dissolubility in soils could be the reason and in such cases available phosphorus form of $\left(\mathrm{H}_{2} \mathrm{PO}_{4}^{-}\right)$in soil [34] are converted to unavailable forms of $\mathrm{H}_{2} \mathrm{O}_{4}{ }^{2-}$ and $\mathrm{PO}_{4}{ }^{3-}$ [82] thus making phosphorous availability in soils very limiting [83]. The higher values of available phosphorus without pollution in Figure 2 confirmed the masking effects of crude oil on phosphorus availability.

On its own, the increased values of exchangeable bases with an increase in oil pollution are attributed to an increase in $\mathrm{pH}$, organic carbon of the soils with oil pollution. Our results contrasted $[84,85,76]$ who obtained a decrease in exchangeable bases with an increase in oil pollution. Results revealed the dominance of exchangeable calcium to magnesium, sodium, and potassium in studied soils which followed similar trends with total exchangeable bases. This is a strong indication that the studied soils were highly weathered [86]. Despite the increased values of $\mathrm{Ca}^{2+}, \mathrm{Mg}^{2+}$ and $\mathrm{k}^{+}$following oil pollution, the values were still low in soils. [44] documented $\mathrm{Mg}<30 \mathrm{cmolkg}^{-1}$ to be low, $\mathrm{K}$ that is between $0.2-0.30 \mathrm{cmolkg}^{-1}$ low, $\mathrm{Ca}<10=$ low. Based on the ratings there is a possibility of crop yield reduction through poor stem growth, discoloration of leaves, wilting in case of potassium [34]. Total exchangeable acidity as a function of the hydrogen and aluminium content of the soil was inconsistent with increased rates of crude oil pollution in both studies. It ranged from 1.74 to 3.31 in pot experiment to 1.74 to 3.27 in the experiment conducted directly on the field. The above result is caused by the relationship existing between soil $\mathrm{pH}$, organic carbon, and exchangeable acidity [87].

The reduction in plant height supported the findings of $[74,89,12,90]$ who reported reverse trends in plant height with an increase in crude oil pollution on aerial yam (Discorea bulbifere L.). This reduction is as a result of the adverse effects of crude oil in masking the release of nutrients in soil despite the higher value of organic carbon and nitrogen observed in the study. They were rather fixed than mineralized. $[91,12]$ attributed such reduction to the interference of crude oil due to its hydrophobic nature with water and gas exchange leading to drought in the crop physiology. In confirmation [83] stated that spent oil-polluted soils remain unsuitable for plant production unless it is remediated depending on the soil, rate of pollution, and environment. Other contributory factors could be impedance to root penetration and development caused by soil compaction which also affects the aeration status of the soil. The observed inhibition of plant height in maize seedlings grown in soils treated with $60 \mathrm{ml}$ of the oil corresponds with the report of [82]. The inconsistence of results of plant height in pot experiment is supported by [90] who reported the possibility of a lower concentration of crude oil in supporting plant growth.

The reduction in leaf area index is caused by the reduction of available phosphorus as a result of pollution by crude oil. This affects the capacity to photosynthetically absorb light radiation hence, poor adventitious root growth, low dry matter yield [92]. In support of $[92,93]$ reported that the reduction and depression in plant height of maize grown in crude oil polluted soils probably led to a reduction in leaf length and width thus affecting leaf area. Low leaf area index affects the photosynthetic ability of crops which in turn leads to the poor yield of crops. [94] ascribed increased plant productivity to the photosynthetic traits of leaves of the plant.

The result obtained in dry matter yield is similar to the findings of [12,74], and could be explained by the presence of stunning, chlorosis, wilting all associated with nutrient deficiency as a result of crude pollution on the soil. All these agree that crude oil pollution can lead to yield retardation. In support [95] citing [96] reported that reduced dry matter yield could be traced to abiotic environmental stress which is connected to oxidative stress, increased senescence which could shorten plant maturity.

\section{Conclusion}

The study showed a significant effect of crude oil in soil and corn growth parameters. The properties of the soil that were critically affected include: bulk density, moisture content, particle size fractions, soil $\mathrm{pH}$, soil organic carbon, total nitrogen, available phosphorus etc. Retarded plant height, leaf area index, and reduced dry matter yield and structural efficiency of the crops were observed. In some cases, lower levels of crude oil increased plant height. Results obtained showed impact of crude oil in both studies. Based on the findings of this study, the following recommendations are made: Crude oil spillage and bunkering should be avoided, and where they occur, the soil should be remediated immediately. In cases where there are other lands for farming, polluted farms should be avoided otherwise farming in those areas should be minimized to reduce losses. Efforts geared towards reducing the degradation of hydrocarbons through bioremediation could be helpful. Results obtained in potted experiments can be used to extrapolate results under field conditions especially in high security risk areas. The result of this study will be valuable to environmentalists, Soil scientists, agronomists, biologists, and government and other relevant bodies in solving the problem of food insecurity. Further research on the quality of crops grown in crude oil polluted soils is recommended be conducted.

\section{Acknowledgment}

a) The authors appreciate the management of Soil Science and Technology certified the Laboratory Federal University of Technology Owerri. 


\section{References}

1. Amaded K (2019) Crude oil, its types, uses and impacts.

2. Odu CTI (1977) Microbiology of soils contaminated with petroleum hydrocarbons natural rehabilitation and reclamation of soil affected. Institute of Petroleum Technology Effurun, Delat State 1: 77-105.

3. Marinescu M,Toti M,Tanase V, Carabulea V, Plopeanu G, et al. (2010) An assessment of the effects of crude oil pollution on soil properties Annals of Food Science and technology 11(1): 94-99.

4. Pepper LL, Gerbal CP, Brusseau ML (1996) Pollution Science, Academic Press, pp. 1-397.

5. Odewumi A (1987) Oil Pollution in Nigeria: A Report on Environmental Pollution (Shell Pet. Dev. Co. Nigeria).

6. Agbogidi MO, Eshegbeyi OF (2006) Performance of Dacryodes edulis seeds and seedling in crude oil-contaminated soil. Journal of sustainable forestry 22(3-4): 1-13.

7. Abosede EE (2013) Effect of Crude Oil Pollution on some Soil Physical Properties. IOSR Journal of Agriculture and Veterinary Science (IOSRJAVS) 6(3): 14-17.

8. Ekundayo EO, Obuekwe O (2000) Effects of an oil spill on soil physico-chemical properties of a spill Site in a Typic Udipsamment of the Niger Delta Basin of Nigeria. Environmental Monitoring and Assessment 60(2): 235-249.

9. Roberts HJ (1997) Oil contamination soil and some reclamation. J Soil Science 24: 231-245.

10.Agbogidi OM (2011) Effects of crude oil contaminated soil on Biomass accumulation in Jatropha curcas L. seedlings. Journal of Ornamental and horticultural plants 1(1): 43-49.

11. Osuagwu AN, Okeigbo AU, Ekpo IA, Chukwura PN, Agbor RB (2013) Effects of crude oil pollution on growth parameters, chlorophyll content and bubils yield in air potatoe (Discorea bulbifera L.). International Journal of Applied Sciences and Technology 3(4): 37-42.

12. Smith MJ, Flowers TH, Duncan HJ, Alder J (2006) Effects of polycyclic aromatic hydrocarbons on germination and subsequent growth of grasses and legumes in freshly contaminated soil and soil with aged PAHs residues. Environmental pollution 141(3): 6519-6525.

13. Oyem ILR, Oyem IL (2013) Effects of Crude Oil Spillage on Soil PhysicoChemical Properties in Ugborodo Community. International Journal of Modern Engineering Research (IJMER) 3(6): 3336-3342.

14. Achuba FI (2006) The effect of sub lethal concentrations of crude oil on the growth and metabolism of cowpea (Vigna unguiculata) seedlings. Environmentalist 26: 17-20.

15. Adam G, Duncan HJ (2002) Influence of Diesel Fuel on Seed Germination. Environ Pollut 120(2): 363-370.

16. Vavrek MC, Campbell WJ (2002) Contribution of seed banks to freshwater wetland vegetation recovery. Louisiana Applied and Educational Oil Spill Research and Development Program, OSRADP. Technical reports series, pp. 0-12.

17. Encyclopedia Britannica (2020) Corn Plant.

18. Kogbe JOS, Adediran JA (2003) Influence of nitrogen, phosphorus and Potassium application on yield of maize in the Savannah zone of Nigeria. African Journal of Biotechnology 2(10): 345-349.

19.FAO (2002) World Agriculture towards 2015/2030. Summary Report. FAO, Rome, Italy.

20.Agbogidi OM, Erutor PG, Akparobi SO (2007) Effects of crude oil levels on the growth of maize (Zea mays L.). American Journal of Food Technology 2(6): 529-535.
21. OECD-FAO Agricultural outlook 2029-2029 Chapter 3. Cereals, pp. 1-29.

22. UN (2015) Sustainable development goals.

23. FAO (2019) Crop prospects and food situation-Quarterly Global report. 4, Rome.

24. Paliwal RL, Grandnos G, Lafitte HR, Voice AD (2000) Tropical maize: Improvement an production. FAO, Rome, Italy, pp.1-363.

25. FEDLAR (1990) The reconnaissance survey of Imo State Nigeria (1:250000). Soil Report, p. 133.

26. Orajaka SO (1975) Geology. In: Ofomata GEK (Ed.), Nigera in maps. The Eastern States, Ettiope Benicity Nigeria. Publishers, pp. 5-7.

27. Agim LC, Igwe CA (2019) Sediment yield, detachment, and runoff from soil under selected parent materials in Southeastern Nigeria. Nigerian Journal of Soil Science 29(1): 35-44.

28. Onweremadu EU, Ejiogu ENO (2012) Soil fertility indicators low-imput agriculture in communities of southeastern Nigeria. Greener Journal of Agricultural Sciences 2(7): 311-315.

29. NIMET (2012) Seasonal Rainfall predictions and socioeconomic implications for Nigeria. pp. 1-22.

30. Dwyer LM, Stewart DW (1986) Leaf area development in field- grown maize. Agron J 78(2): 334-343.

31. Gee GW, Or D (2002) Particle size analyses. In methods of soil analyses. In: Dane DJ, Topps GC (Eds.), Part 4. Physical methods. SSSA book services.5, ASA, SSSA. Madison, W.I, pp. 225-293

32. Saxton KE, Rawls WJ, Romberger, Papendick JC (2006) Estimating generalized soil water characteristics from texture. Trans Asae 50: 1031-1035.

33. Brady NC, Weil RR (1999) Nature and properties of soils. (12 ${ }^{\text {th }}$ edn), Hall Inc, New Jersey

34. Gardner WH (1982) Water content. In: Klute A (Ed.), Methods of soil analysis, Part 1, physical and mineralogical properties. $\left(2^{\text {nd }}\right.$ edn $)$, American society of agronomy, American society of soil science, Madison, pp. 493-544.

35. Hendershot WH, Lalande $H$, Duquette $M$ (1993) Soil reaction and exchangeable acidity. In: MR Carter (Ed.), Soil sampling and methods of soil analyses. Canadian Society of soil science. Lewis Publishers, London, pp. 141-145.

36. Nelson DW, Somers LS (1982) Total organic carbon, and organic matter. In: Page LA, Miller RH, Keeney DR (Eds.), Methods of soil analysis, Part 2. ( $2^{\text {nd }}$ edn), Agronomy Monograph, 9: 595-624. American Society of Agronomy Madison, Wisconsin.

37. Bremner JM, Mulvaney CS (1982) Total Nitrogen. In: Page LA, Miller RH, Keeney DR (Eds.), Methods of soil analysis, Part 2. ( $2^{\text {nd }}$ edn), Agronomy Monograph. American Society of Agronomy Madison, Wisconsin 9: 595-624.

38. Olsen SR, Somers LE (1982) Phosphorus. In: Miller RH, Keeney DR (Eds.), Methods of Soil analyses. Chemical and microbial properties. Madison, W.I., pp. 159-165.

39. Mclean EV (1982) Aluminum. Page LA, Miller RH, Keeney DR (Eds.), Method of soil analysis, Part 2. Am Soc Agron Madison, W.I., pp. 978998.

40. Thomas GW (1982) Exchangeable cations. In: Page AL (Ed.), Method of soil analysis, part2. Chemical and microbiological properties, ( $\left.2^{\text {nd }} e d n\right)$, Agronomy, Wiscosine, pp. 159-165.

41. Marinescu M, Toti M, Tanase V, Plopeanu G, Calciu I, (2001) The effects of crude oil pollution on physical and chemical characteristics of soil. Research Journal of Agricultural Science 43(3): 125-129. 
42. Chikezie IA, Eswaran H, Asawalam DO, Ano AO (2010) Characterisation of two bemchmark soils of contrasting parent material in Abaia State, South eastern Nigeria. Global Journal of pure and applied Sciences 16(1): 23-29.

43. Landon ER (1991) Booker tropical soil manual: A hand book for surveys and agricultural land evaluation in tropics and sub tropics. Longman Scientific and Technical, Essex, New York.

44. Heard JR, Kladivko EJ, Mannering JV (1988) Soil macro porosity, hydraulic conductivity and air permeability of silty soils under long term tillage in Indiana. Soil Tillage Research 11(1): 1-18.

45. Wang Y, Feng J, Lin Q, Lyu X, Wang X, et al. (2013) Effects of Crude Oil Contamination on Soil Physical and Chemical Properties in Momoge Wetland of China. Chinese Geographical Science 23(6): 708-715.

46. Chukwuma MC, Agim LC, Ugwoajanma MO, Obasi NS, Okoli NA, et al. (2009) Concentration and toxicity of selected heavy metal in a spentoil polluted typic Paleudult, South eastern Nigeria. International Journal of Agriculture and Rural Development 11(2): 77-81.

47. Wang S, Xu Y, Lin Z, Zhang J, Norbu N, et al. (2017) The harm of petroleum-polluted soil and its remediation research. AIP Conference Proceedings 1864: 020222

48. Plessis JD (2003) Maize production Directorate Agricultural Information Services Department of Agriculture in cooperation with ARC-Grain Crops Institute South Africa, pp. 1-35.

49. Uquetan UI, Osang JE, Egor AO, Essoka PA, Alozie SI, et al. (2017) A case study of the effects of oil pollution on soil properties and growth of tree crops in Cross River State, Nigeria. International Research Journal of Pure and Applied Physics 5(2): 19-28.

50. Chukwu ED, Udoh BT (2014) Effects of postulation on growth of indigenous bacteria in some soil chemical properties in Ikot Abasi Nigeria. This is title of the paper presented at the Annual Conference of Soil Science Society of Nigeria 10-14 $4^{\text {th }}$ March, pp. 83-88.

51.Collin F, Deille D (2003) Effects of postulation on growth of Indigenous bacteria in some Antarctic soil contained with oil hydrocarbons. Journal of oil and gas science Technology Review 58: 469-479.

52. Uzoije AP, Agunwamba JC (2011) Physiochemical properties of soil in relation to varying rates of crude oil pollution. Journal of Environmental Science and Technology 4(3): 313-323.

53. Eshett EL, Omueti JA, Juo ASR (1985) Soil chemical properties and mineralogy in relation to South-eastern Nigeria. Nigerian Journal of Agricultural Science 12: 377-386.

54. He LJ, Wei DZ, Zhang WQ (1999) Research of microbial treatment of petroleum contaminated soil. Advances in environmental science, $7(3)$ : 110-111.

55. Obi ME, Nnabude PC (1988) The effects of different management practices on the physical properties of a sandy loam soil in southeastheren Nigeria. Soil Tillage Res 12(1): 81-90.

56. Kisic I, Mesic S, Basic F (2009) The effect of drilling fluids and crude oil on some chemical characterization of soil and crops. Geoderma 149 (34): 209-216.

57. Leahy JG, Colwell RR (1990) Microbial degradation of hydrocarbons in the environment. Microbiological Reviews 54(3): 305-315.

58. Zuofa P, Loanathan N, Isirimah O (1988) Effects of crude oil applications to soil on the growth and yield of maize, okro and cassava in Nigeria. Oil and Chemical Pollution 4(4): 249-259.

59.Ngobiri CN, Ayuk AA, Awunso II (2007) Differential degradation of hydrocarbon fractions during bioremediation of crude oil polluted sites in Niger Delta Area. L Chem Soc Nig 32: 151-158. 60.0suji LC, Egbuson EG, Ojinnaka CM (2006) Assessment and treatment of hydrocarbon inundated soils using inorganic nutrient (NPK) supplements. II. A case study of Eneka oil spillage in Niger Delta, Nigeria. Environmental Monitoring and assessment 115(1-3): 265-278.

61. Li M, Zheng XL, Tong L (2009) Influence of petroleum pollution on the permeability of soils. Acta Scientirum naturalium Universitatis Sunyatsemi 48(2): 122-123.

62. Wang X, Feng J, Wang J (2009) Petroleum hydrocarbon contamination and impact on soil characteristics from oilfield in Momoge Wetland. Environmental Science 30(8): 2384-2401.

63. Njoku KL, Akinola MO, Oboh BO (2009) Phytoremediation of crude oil contaminated soil. The effect of growth of glucine max on the physicchemistry and crude oil contents of soil. Nat Science 7: 22-30.

64. Nudleman NS, Rios IS, Katusich O (2002) Fate of the oil residuals in Patagonian soils effects of the environment exposure time. Journal of Environmental Remediation 3: 1-8

65. Unamba Opara I (1982) Comparison of the carbon and nitrogen contents and their relationships to other properties in some important soils of southeastern Nigeria. Beitrage Trop Landswitsch Verteinarmed 20(2): 167-176

66. Agim LC, Osuji GE, Onweremadu EU, Ndukwu BN, Osuaku S (2012) Seasonal dynamics of soil organic carbon and total nitrogen in soils under different land uses in Owerri Southeastern Nigeria. Agro Science Journal of Tropical Agriculture, Food, Environment, and Extension 11(1): 43-54.

67. Akamigbo FOR (1999) Influence of land uses on soil physical properties of the humid tropical ecology of south eastern Nigeria. Nigeria Agricultural Journal 30: 59-76.

68. Onasanya SO (1992) The relationship between topographic location. Soil properties and cultural management and the productivity . Maizesoybean intercrop. A Ph.D thesis in Depart. Of Agronomy, University of Ibadan, Nigeria, p. 319

69. Bot A, Benites J (2005) Important of soil organic matter, Key to drought resistant in soil and sustained food production, FAO Soil Bulletin, Rome.

70. Tiessen HJ, Stewart JWB, Bettany JR (1982) Cultivation effects on the amounts and concentration of carbon, nitrogen and phosphorus in grassland soils. Agronomy Journal 74: 831-835.

71. Yao MK, Angui PKT, Konate S, Tondon J, Tano E, et al. (2010) Effects of land use types on soil organic carbon and nitrogen in Mid-West Cote $\mathrm{d}$ ivoire. European Journal of Scientific Research 40(2): 211-222.

72. Essien OE, John (2010) Impact of crude oil spillage pollution and chemical remediation of agricultural soil properties and crop growth Journal of applied sciences Management 14(4): 147-154.

73. Orluchukwu JA, Ogburia MN (2018) Growth and Yield Performance of text crops under oil palm sludge application in Humid agro ecology of Rivers State of Nigeria. Journal of Agriculture and veterinary medicine 11(5): 29-33.

74. Isirimah ON, Zuofa K, Loganathan R (1989) The effects of crude oil on maize performance and soil chemical properties of the Humid Forest Zone of Nigeria. Discovery and Innovations 1(3).

75. Obasi NA, Eberechukwu E, Anyanwu DI, Okorie UC (2013) Effects of organic manures on the physicochemical properties of crude oil polluted soils. African Journal of Biochemistry Research 7(6): 67-75.

76. Onuh MO, Maduekwe DK, Ohia GU (2008) Effects of poultry manure and cow dung on physical and chemical properties of crude oil polluted soil. Sci World J 3(2): 45-50. 
77. Havlin JL, Beaton JD, Tisdale SL, Nelson WL (1999) Soil fertility and fertilizers. (6 $6^{\text {th }}$ edn), Prentice Hall. Upper Saddle River, NJ, p. 499.

78. Adepetu JA (1986) Soil fertility and fertilizer requirements in Oyo, Ogun, and Ondo States of Nigeria. Federal Department of Agriculture and Land Research publication.

79. Smart Fertilizer Management (2011) Phosphorus in soils and plants.

80. Taurus (2020) Agriculture nutrient profile: Phosphorus part 1.

81. Asuquo FE, Ibanga L, Idungafa J (2001) Effects of Qua Iboe crude oil contamination on germination and growth of okra. This is the title of paper presented at the $27^{\text {th }}$ Annual Conference Soil Science Society of Nigeria, pp. 309-316.

82. Atuanya EI (1987) Effects of waste engine oil pollution on physical and chemical properties of soil. A case study of waste oil contaminated Delta soil in Bendel State. Nigeria Journal of Applied Sciences 5: 155176.

83. Ekundayo JA, Aiseni N, Benker-Coker MO (1989) The effects of drilling some waste and burrow pit in western operational Areas of shell Petroleum Development Company of Nigeria Limited on the soil and water quality of the areas in Benin. Environmental consultancy Service Unit, University of Benin, pp. 57-71.

84. Abii TA, Nwosu PC (2009) The effects of oil spillage on the soil of Eleme in Rivers State of the Niger- Delta Area of Nigeria. Research Journal of Environmental Sciences 3: 316-320.

85. Olade MA 1987, Heavy metal pollution and the need for monitoring: Illustrated for developing countries in West Africa. Lead, Mercury, Cadmium and Arsenic in the Environment. In: Hutchrson CTC, Mean KM (Eds.), John Wiley and Sons Ltd, New York, USA, p. 555.

86. Foth HD (1990) Fundamentals of soil science. ( $8^{\text {th }}$ edn), John Wiley and sons. Inc. New York, USA, p. 360.
87. Chukwumatiz JA, Ibanibo GC, Adedokun OM (2019) Response of Maize (Zea mays) on Crude Oil Polluted Soil after One Month of Remediation with Spent Mushroom Substrate. Advances in Research 20(4): 1-8.

88. Okonokhua BO, Ikhajiagb EB, Anoliefo GO, Eemede TO (2007) The Effects of Spent Engine Oil on Soil Properties and Growth of Maize (Zea mays L.). J Appl Sci Environ Manage 11(3): 147-152.

89. Okolo JC, Amadi EN, Odu CTI (2005) Effects of soil treatments containing poultry manure on crude oil degradation in a sandy loam soil. Appl Biol Environ Res 3(1): 47-53.

90. De Jong E (2000) The effect of crude oil spill on cereals. Environmental pollution series 22(3): 187-196.

91. Australian government, department of health and ageing office (2008) The biology of maize Zea Mays L. spp mays (maize or corn) 1: 1-81.

92.Cutler JM, Rains OW, Loomis RS (1987) The importance of cell size in the water relations of plant. Physiol Plants 40(4): 225260.

93. Yabiku T, Ueno O (2017) Variations in physiological, biochemical and structural traits of photosynthesis and resources use efficiency in maize and teosintes (NADP-ME-TypeC ${ }_{4}$ ). Plant production Science 20(4): 448-458.

94. Odukoya J, Lambert R, Sakrabani R (2019) Understanding the impact of crude oil and its induced abiotic stresses on agrifood Production. A review. Horticulturae 5(2): 47.

95. Jia J, Liu Y, Li G (2009) Contamination characteristic and its relationship with physicochemical properties of oil polluted soils in oilfields of China. Chemical Industry and Engineering Society of China 60(3): 726732.

96. Wang Y, Frei M (2011) Stressed food-the impact of abiotic environmental stresses on crop quality. Agric. Ecosyst Environ 141(34): $271-286$ 